\title{
Ecomparism, sebuah konsep perencanaan wisata Pantai Teloek Dalam - Bintan, Provinsi Kepulauan Riau
}

\author{
Ridwansyah Trisnanda Putra, Pitria Ramadanti, Dimas Muhammad Thoifur, Hindun Hestiningsih, \\ Risalah Rabbani Ramadhan, Ray March Syahadat*, Priambudi Trie Putra \\ Prodi Arsitektur Lanskap, Fakultas Teknik Sipil dan Perencanaan \\ Institut Sains dan Teknologi Nasional, Indonesia \\ *E-mail: ray.arl@istn.ac.id
}

\begin{abstract}
Ecomparism, a Concept for Tourism Planning of Teloek Dalam Beach - Bintan, Province of Kepulauan Riau. The aim of this planning was to create an ecological tourism landscape that remains compact at Teloek Dalam Beach. In this case compact means complete in term of harmonizing the man-made and natural landscape to support various activities both on the terrestrial and aquatic. The analysis used included some aspects such as environmental, visual, social, ecosystem, vegetation, animals, willingness to pay, carrying capacity, and environmental quality assessment. The results show that the visual aspect is quite good with feature of white sands, blue sea, and sunrise. There are 23 species of animals, 9 species of seagrass, and 3 dominate species of coastal vegetation. The carrying capacity for this site is 12.493 people. With average 4 hours visit time, the assumption used can only accommodate visitors every four hours for 3.123 people and 9.370 visitors staying. The concept of ecomparism is a concept of tourism landscape planning that does not exclude ecological principles despite creating compact area planning. The planning results from three concepts of space which are divided into core, buffer, and utilization zones. The utilization zone is divided into 6 spaces based on 13 activities.
\end{abstract}

Keywords: carrying capacity, compact area, ecology, environmental quality assessment, landscape.

\section{Pendahuluan}

Provinsi Kepulauan Riau (Kepri) memiliki jumlah pulau sebanyak 1.796 pulau baik pulau besar maupun kecil yang tersebar di Laut Natuna di sisi selatan Laut Cina Selatan dan Laut Natuna Utara. Provinsi ini sangat unik karena 95\% wilayahnya merupakan perairan. Keunikan lain dari provinsi ini yaitu berbatasan langsung dengan negara-negara ASEAN seperti Singapura, Malaysia, Kamboja, dan Vietnam (BPS Kepulauan Riau, 2017).

Pulau Bintan merupakan salah satu pulau utama di provinsi tersebut karena di pulau inilah terletak ibukota Provinsi Kepri. Luas Pulau Bintan mencapai 1.173 km2 (BPS Kepulauan Riau, 2017). Area sebelah timur memiliki lanskap yang luar biasa karena memiliki banyak pantai pasir putih, perairan yang jernih, dan cukup tenang dari keramaian. Salah satu pantai yang cukup populer di pulau ini yaitu Pantai Teloek Dalam.

Pantai Teloek Dalam terletak di sebelah timur Pulau Bintan. Pantai ini merupakan bagian dari Kawasan Pantai Trikora dan berada di utara Serumpun Padi Mas Resort. Pantai ini memiliki potensi yang besar karena memiliki nilai estetik yang tinggi. Namun sayangnya hingga saat ini belum dimanfaatkan. Padahal jika melihat potensi yang dimilikinya, pantai ini berpeluang untuk menarik wisatawan tak hanya wisatawan domestik tapi juga mancanegara. Alasan yang mendasarinya adalah letak geografisnya yang dekat dengan negara tetangga. Peluang selanjutnya, pemerintah pusat sesungguhnya telah merencanakan kawasan ini masuk dalam kawasan ekonomi khusus (KEK) yang dikenal dengan KEK Batam, Bintan, Karimun.

Kegiatan perencanaan lanskap Pantai Teloek Dalam dianggap perlu dilakukan untuk mencegah pembangunan yang tidak berorientasi pada keberlanjutan lingkungan. Kegiatan perencanaan juga diperlukan untuk menjaga kualitas yang dimiliki Pantai Teloek Dalam sehingga tidak menurun. Tujuan yang ingin dicapai dalam perencanaan ini yaitu terciptanya lanskap wisata Pantai Teloek Dalam yang ekologis, kompak, serta memperhatikan keberlanjutan lanskap alami maupun buatan yang mampu memenuhi aktivitas pengguna di dalamnya. 


\section{Metode}

Penelitian dilakukan di Pantai Teloek Dalam, Pulau Bintan, Provinsi Kepri pada Januari 2018 (Gambar 1). Penelitian ini menggunakan pendekatan deskriptif yang dikuantitatifkan dengan melakukan pembobotan, skoring, serta peringkat seperti yang dilakukan oleh Muflih et al. (2015). Nilai skor berada antara 1 hingga 4. Semakin tinggi nilai skor yang diberikan, semakin baik variabel yang dinilai. Standar mengacu pada Yusiana et al. (2011) dan Makalew et al. (2013) yang dikombinasikan oleh penulis. Penilaian yang dilakukan antara lain kualitas akuatik dan terestrial (Tabel 1), potensi objek dan daya tarik (Tabel 2), serta ekologi dan wisata (Tabel 3). Data dikumpulkan dengan cara wawancara kepada 36 responden, observasi, dan juga menggunakan data sekunder yang diperoleh dari penelitian yang dilaporkan oleh llahi et al. (2016). Formula yang digunakan untuk menentukan tingkat kualitas menggunakan formula sebagai berikut:

$$
\text { Kualitas }=\left(\sum \text { skor maksimal }-\sum \text { skor minimum }\right) / 3
$$

Dengan demikian, sebaran tingkat kualitas masing-masing aspek dapat dilihat pada Tabel 4. Analisis yang juga dilakukan pada studi ini yaitu analisis tautan lingkungan, visual, sosial, ekosistem, vegetasi, dan satwa yang disajikan secara deskriptif. Analisis willingness to pay juga dilakukan dengan melakukan survei kepada pengunjung Pantai Teloek Dalam dengan teknik convenience sampling. Untuk mencapai keberlanjutan aspek daya dukung terhadap merupakan hal yang tidak boleh luput dari perhatian. Kelebihan daya dukung akan mengakibatkan terjadinya penurunan kualitas lanskap (Inskeep, 1991; Gunn, 1994; Holden, 2000). Dengan demikian pada kajian ini turut dilakukan analisis daya dukung dengan beberapa asumsi dengan formulasi sebagai berikut:

Daya dukung = Luas area / standar kenyamanan 1 orang manusia

Kapasitas per jam = Daya dukung $/$ rata-rata lama waktu berkunjung

Kapasitas menginap = Daya dukung - kapasitas per jam

Keterangan:

$$
\mathrm{BL}=(\mu \times \mathrm{KI})
$$

$\mathrm{BL}=$ Jumlah pemanfaatan bangunan lanskap untuk menginap (unit)

$\mu \quad=$ Persen asumsi pemanfaatan bangunan lanskap untuk menginap (\%)

$\mathrm{KI}=$ Kapasitas pengunjung menginap (orang)

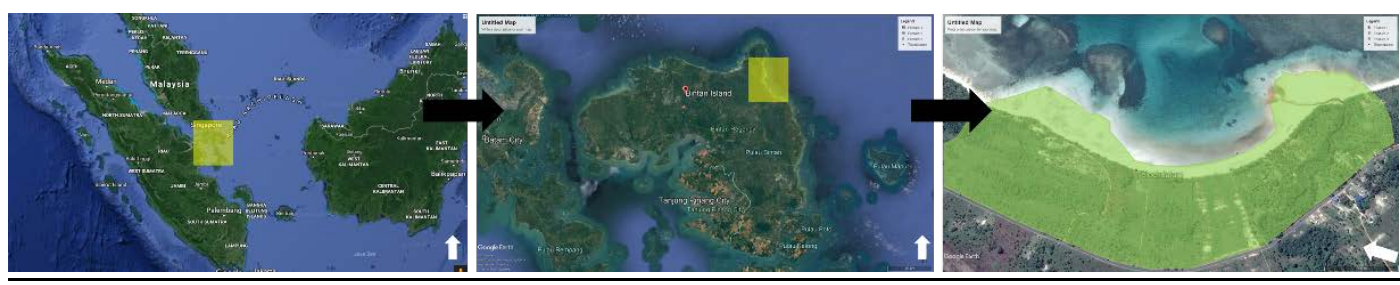

Gambar 1. Lokasi Studi Kepulauan Riau (kiri), Pulau Bintan (tengah), dan Lokasi Tapak (kanan).

\section{Hasil dan Pembahasan}

Pantai Teloek Dalam memiliki sebelas tautan lingkungan yang kemudian dianalisis untuk diperoleh informasi mengenai potensi dan permasalahannya sebagai dasar perencanaan (Gambar 2a). Tautan lingkungan dibutuhkan untuk melihat pengaruh tapak terhadap lingkungan sekitar maupun sebaliknya. Setelah identifikasi tautan lingkungan, maka dilakukan analisis ekosistem. Analisis ekosistem perlu dilakukan karena pesisir pantai merupakan ekosistem kompleks yang menghubungkan dua atau lebih ekosistem dalam hal ini akuatik dan terestrial. Fitriana et al. (2018) menyatakan bahwa tidak seluruh area pesisir pantai dapat dimanfaatkan secara langsung karena terdapat area-area sensitif yang apabila dimanfaatkan langsung dapat membahayakan pengguna atau lingkungan itu sendiri. Berdasarkan hasil analisis struktur lanskap patch dan 
corridor, ekosistem yang ada di Pantai Teloek Dalam terdiri atas tiga yaitu ekosistem pantai, ekosistem padang lamun, dan ekosistem sungai yang memiliki karakter yang berbeda satu sama lain. Pertemuan antar ekosistem (ecotone) tersebut menjadikan area pada Pantai Teloek Dalam ini kaya akan komponen biotik dan abiotik. Keunikan lainnya adalah adanya estuari di pasir putih pada sisi selatan pantai (Gambar 2b).

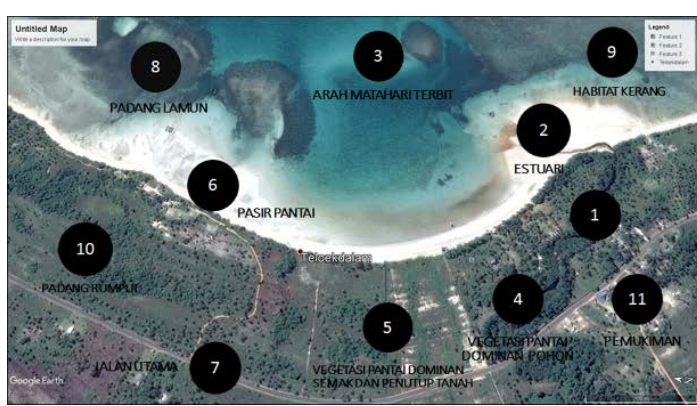

a. Tautan Lingkungan

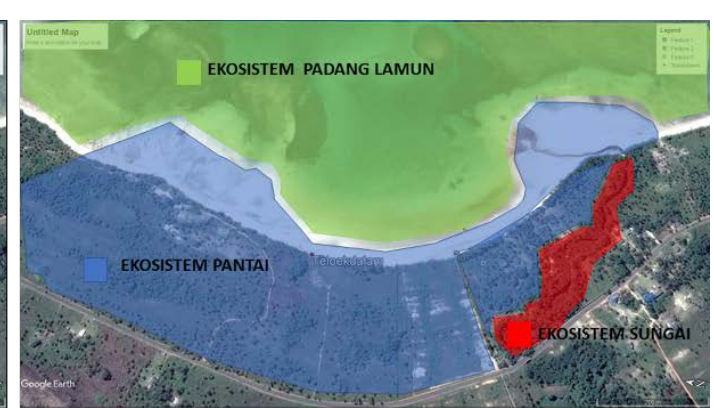

b. Ekosistem Pantai Teloek Dalam

Gambar 2. Tautan Lingkungan dan Keragaman Ekosistem Pantai Teloek Dalam

Berdasarkan analisis visual, Pantai Teloek Dalam memiliki potensi view pasir putih yang panjang, perairan yang jernih, dan karena menghadap timur maka pantai ini dapat menjadi tempat yang tepat untuk menikmati sunrise. Dengan demikian, pantai ini memiliki peluang untuk dikembangkan menjadi salah satu kawasan resort. Hasil observasi dan penelusuran literatur menunjukkan bahwa terdapat 23 satwa akuatik yang terdiri dari empat golongan yaitu gastropoda, bivalvia, crustacea, pisces, dan chepalopoda (llahi et al., 2016). Gonggong (Strombus sp.) merupakan satwa khas dari daerah ini. Satwa yang ada di tapak perlu dijaga kelestariannya sehingga meskipun adanya pembangunan tidak mengganggu keberadaanya tetapi dapat mendukung kawasan.

Selanjutnya, hasil observasi vegetasi terestrial yang mendominasi yaitu kelapa (Cocos nucifera), cemara laut (Casuarina equisetifolia), dan bakau (Rhizopora sp.). Vegetasi akuatik yang terdapat di Pantai Teloek Dalam terdapat pada ekosistem padang lamun. Vegetasi di padang lamun tergolong sebagai submerged plant (Nasrullah et al. 2016; Yong et al., 2010). Terdapat sembilan spesies lamun yang dapat ditemukan antara lain Cymodocea serrulata, Enhalus acoroides, Halodule pinifolia, Halodule uninervis, Halophila desciepiens, Halophila ovalis, Syringodium isotifolium, Thalassia hemprichii, dan Thalassodendron ciliatum (llahi et al., 2016). Tersedianya vegetasi di lokasi bermakna bahwa sudah memiliki sistem ekologi sehingga keberadaannya perlu dijaga. Apabila akan dilakukan penambahan vegetasi, maka disarankan menggunakan jenis-jenis vegetasi yang telah ada di lokasi tapak. Hasil penelitian yang dilakukan oleh Syahadat et al. (2018), menyatakan bahwa beberapa vegetasi eksisting di ruang terbuka hijau (RTH) memiliki indeks nilai penting. Indeks nilai penting yang tinggi menggambarkan bahwa vegetasi tersebut memiliki tingkat toleran yang tinggi terhadap lingkungannya sehingga dapat bertahan pada dinamika lingkungan setempat.

Kualitas lingkungan akuatik dan terestrial, ekologi dan wisata, serta objek wisata dan atraksi pada Pantai Teloek Dalam berada pada kategori tinggi yang dapat dilihat pada Tabel 5 , Tabel 6 , dan Tabel 7. Melihat dengan banyaknya peluang dan potensi yang ada di Pantai Teloek Dalam, maka melalui perencanaan lanskap ini diajukan sebuah konsep yang disebut ecomparism. Ecomparism berasal dari kata eco-compact tourism yang merupakan sebuah konsep yang memadukan antara wisata yang tidak merusak ekosistem atau selaras dengan ekologi, namun tetap kompak. Kompak yang dimaksud yaitu besarnya tourism supply dalam bentuk atraksi serta sarana dan prasarana. Kompak juga mengacu pada tersedianya sumber daya alam, budaya, serta sosial yang ada pada kawasan tersebut. Konsep eco dalam ecomparism bukanlah konsep ekowisata yang tidak boleh menambah maupun mengurangi apa yang ada di alam (manusia sebagai bagian dari ekosistem). Terminologi tersebut mengacu pada Ceballos-Lascurain (1987) yang menyatakan ekowisata merupakan lingkungan alami, belum terjamah, serta kegiatannya terbatas dan dikhususkan hanya untuk mengagumi dan mempelajari alam tersebut. Konsep ecomparism merupakan konsep yang mempertimbangkan aspek-aspek ekologis suatu perencanaan tapak untuk meminimalkan penurunan kualitas 
lingkungan untuk mencapai keberlanjutan. Meskipun terdapat area yang baru dan munculnya beragam aktivitas namun dengan menggunakan pendekatan beberapa analisis diharapkan dapat meminimalkan terjadinya gesekan ekologi. Prinsip yang digunakan yaitu segitiga keberlanjutan yang terdiri atas ekologi (planet), ekonomi (profit), dan sosial-budaya (people).

Tabel 1. Standar penilaian terhadap aspek kualitas lingkungan akuatik dan terestrial

\begin{tabular}{|c|c|c|c|}
\hline Unsur & Bobot & Sub-unsur & Keterangan \\
\hline \multicolumn{4}{|l|}{ A. Akuatik } \\
\hline \multirow[t]{4}{*}{$\begin{array}{l}\text { Kecerahan } \\
\text { perairan }\end{array}$} & 10 & $>75 \%$ & Sangat sesuai (4) \\
\hline & & $>50-75 \%$ & Sesuai (3) \\
\hline & & $>25-50 \%$ & Kurang sesuai (2) \\
\hline & & $\leq 25 \%$ & Tidak sesuai (1) \\
\hline \multirow[t]{4}{*}{$\begin{array}{l}\text { Kecepatan } \\
\text { arus }\end{array}$} & 10 & $0-0,17 \%$ & Sangat baik (4) \\
\hline & & $>0,17-0,34 \%$ & Baik (3) \\
\hline & & $>0,34-0,51 \%$ & Batas toleransi (2) \\
\hline & & $>0,51 \%$ & Bahaya (1) \\
\hline \multirow[t]{4}{*}{$\begin{array}{l}\text { Substrat } \\
\text { dasar }\end{array}$} & 10 & Pasir & Sangat baik (4) \\
\hline & & Karang berpasir & Baik (3) \\
\hline & & Lumpur & Kurang baik (2) \\
\hline & & Pecahan karang murni & Tidak baik (1) \\
\hline \multirow[t]{4}{*}{$\begin{array}{l}\text { Topografi } \\
\text { laut }\end{array}$} & 10 & Landai & Aktivitas tinggi (4) \\
\hline & & Cukup landai & Aktivitas tinggi (3) \\
\hline & & Terjal & Aktivitas sedang (2) \\
\hline & & Curam & Aktivitas rendah (1) \\
\hline \multicolumn{4}{|l|}{ B. Terestrial } \\
\hline \multirow[t]{4}{*}{ Ekosistem } & 20 & Keaslian ekosistem utuh & Ekosistem utuh (4) \\
\hline & & Keaslian ekosistem rusak <15\% & Ekosistem utuh (3) \\
\hline & & Keaslian ekosistem rusak $15-50 \%$ & Ekosistem terganggu (2) \\
\hline & & Keaslian ekosistem rusak >50\% & Ekosistem rusak (1) \\
\hline \multirow{4}{*}{$\begin{array}{l}\text { Penutupan } \\
\text { lahan } \\
\text { pantai }\end{array}$} & 15 & $>150$ & Penutupan Iahan alami (4) \\
\hline & & $>100-150$ & Penutupan lahan semi alami (3) \\
\hline & & $>50-100$ & Penutupan lahan terbangun (2) \\
\hline & & $\leq 50$ & Campuran (1) \\
\hline \multirow[t]{4}{*}{$\begin{array}{l}\text { Lebar } \\
\text { pantai }\end{array}$} & 10 & $>150$ & Sangat baik untuk wisata (4) \\
\hline & & $>100-150$ & Baik untuk wisata (3) \\
\hline & & $>50-100$ & Kurang baik untuk wisata (2) \\
\hline & & $\leq 50$ & Tidak baik untuk wisata (1) \\
\hline Topografi & 10 & $0-8 \%$ & Aktivitas sangat tinggi (4) \\
\hline
\end{tabular}


Lanjutan Tabel 1

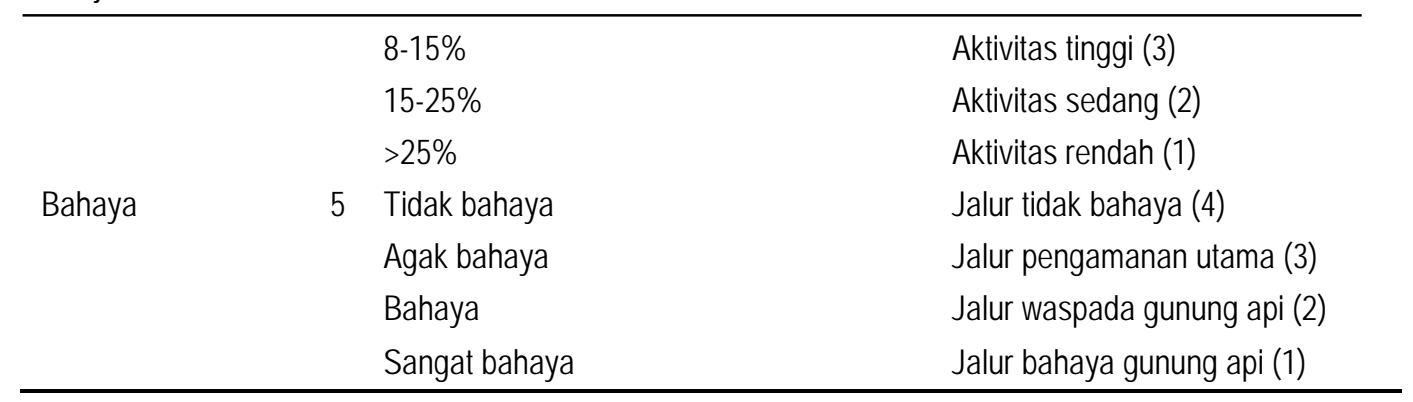

Tabel 2. Standar penilaian aspek potensi objek dan atraksi

\begin{tabular}{|c|c|c|}
\hline Unsur & Sub-unsur & Keterangan \\
\hline \multirow[t]{4}{*}{ Letak dari jalan utama } & $<1 \mathrm{~km}$ & Sangat kuat (4) \\
\hline & $1-2 \mathrm{~km}$ & Kuat (3) \\
\hline & $2-3 \mathrm{~km}$ & Sedang (2) \\
\hline & $>3 \mathrm{~km}$ & Lemah (1) \\
\hline \multirow[t]{4}{*}{ Estetika dan keaslian } & Asli & Sangat kuat (4) \\
\hline & Asimilasi, dominan bentuk asli & Kuat (3) \\
\hline & Asimilasi, dominan bentuk baru & Sedang (2) \\
\hline & Sudah berubah sama sekali & Lemah (1) \\
\hline \multirow[t]{4}{*}{ Atraksi } & Hanya terdapat di tapak & Sangat kuat (4) \\
\hline & Terdapat $<3$ atraksi di tempat lain & Kuat (3) \\
\hline & Terdapat 3-5 atraksi di tempat lain & Sedang (2) \\
\hline & Terdapat $>5$ atraksi di tempat lain & Lemah (1) \\
\hline \multirow[t]{4}{*}{ Fasilitas pendukung } & Tersedia dengan kondisi sangat baik & Sangat kuat (4) \\
\hline & Tersedia dalam kondisi baik & Kuat (3) \\
\hline & Tersedia dalam kondisi kurang baik & Sedang (2) \\
\hline & Tidak tersedia & Lemah (1) \\
\hline \multirow[t]{4}{*}{ Ketersediaan air } & $<0,5 \mathrm{~km}$ & Sangat kuat (4) \\
\hline & $0,5-1 \mathrm{~km}$ & Kuat (3) \\
\hline & $1-2 \mathrm{~km}$ & Sedang (2) \\
\hline & $>2 \mathrm{~km}$ & Lemah (1) \\
\hline
\end{tabular}


Lanjutan Tabel 2

\begin{tabular}{lll}
\hline Transportasi dan aksesibilitas & Jalan aspal, ada kendaraan umum & Sangat kuat (4) \\
& $\begin{array}{l}\text { Jalan aspal berbatu, ada kendaraan } \\
\text { umum } \\
\text { Jalan aspal berbatu, tanpa kendaraan } \\
\text { umum } \\
\text { Jalan berbatu/tanah tanpa kendaraan } \\
\text { umum }\end{array}$ & Kuat (3) \\
& Sangat mendukung & Sedang (2) \\
& Mendukung (1) \\
Dukungan dan partisipasi & Kurang mendukung & Sangat kuat (4) \\
& Tidak mendukung & Kuat (3) \\
& & Sedang (2) \\
\hline
\end{tabular}

Tabel 3. Standar penilaian kualitas aspek ekologi dan wisata

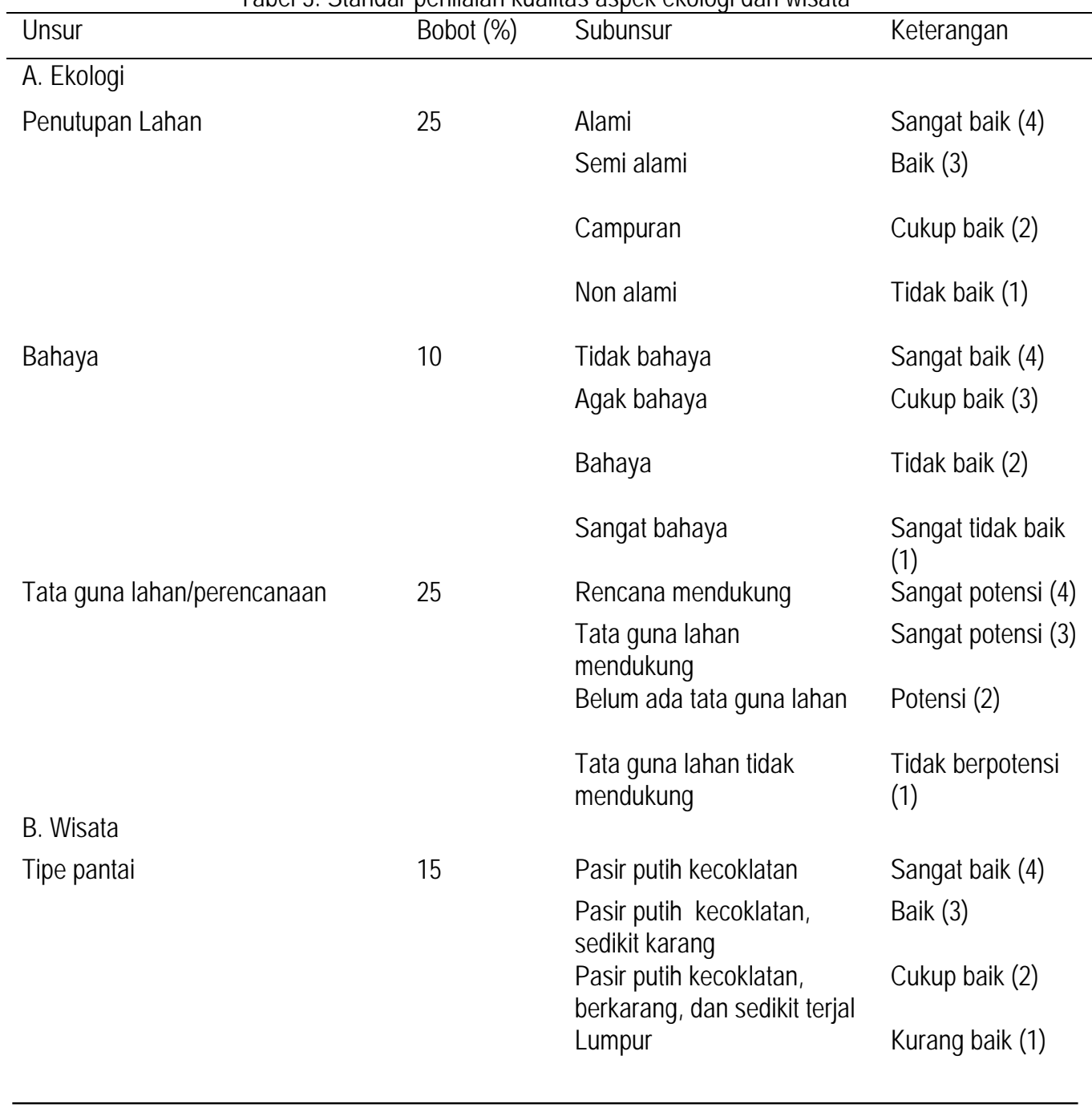


Lanjutan Tabel 3

\begin{tabular}{|c|c|c|c|}
\hline \multirow[t]{4}{*}{ Penutupan lahan pantai } & 15 & Lahan terbuka, mangrove & Sangat baik (4) \\
\hline & & $\begin{array}{l}\text { Semak, belukar rendah, } \\
\text { savana }\end{array}$ & Baik (3) \\
\hline & & Belukar tinggi & Cukup baik (2) \\
\hline & & $\begin{array}{l}\text { Permukiman, fasilitas } \\
\text { wisata }\end{array}$ & Kurang baik (1) \\
\hline \multirow[t]{4}{*}{ Variasi jumlah wisata } & 10 & $>6$ & Sangat variatif (4) \\
\hline & & $5-6$ & Variatif (3) \\
\hline & & $3-4$ & Cukup variatif (2) \\
\hline & & $1-2$ & Kurang variatif (1) \\
\hline
\end{tabular}

Tabel 4. Tingkat kualitas masing-masing aspek

\begin{tabular}{lccc}
\hline Aspek & Rendah & Sedang & Tinggi \\
\hline Akuatik dan terestrial & $100-200$ & $201-300$ & $301-400$ \\
Ekologi dan wisata & $100-200$ & $201-300$ & $301-400$ \\
Potensi objek dan atraksi & $7-12,67$ & $12,68-18,34$ & $18,35-24$ \\
\hline
\end{tabular}

Tabel 5. Hasil penilaian kualitas aspek lingkungan akuatik dan terestrial

\begin{tabular}{lcccc}
\hline \multicolumn{1}{c}{ Variabel } & Bobot & Kriteria & Skor & Nilai \\
\hline A. Akuatik & & & & \\
Kecerahan perairan & 10 & $>75 \%$ & 4 & 40 \\
Kecepatan arus & 10 & $>0,34-0,51$ & 2 & 20 \\
Substrat dasar & 10 & Pasir & 4 & 40 \\
Topografi laut & 10 & Landai & 4 & 40 \\
$\begin{array}{l}\text { B. Teresrial } \\
\text { Ekosistem }\end{array}$ & 20 & Keaslian ekosistem utuh & 4 & 80 \\
Penutup tanah pantai & 15 & Alami & 3 & 45 \\
Lebar pantai & 10 & $>50-100$ & 2 & 20 \\
Topografi laut & 10 & $0-8 \%$ & 4 & 40 \\
Bahaya gunung berapi & 5 & Tidak bahaya & 4 & 20 \\
Total & & & & 345 (tinggi) \\
\hline
\end{tabular}

Berdasarkan hasil keseluruhan analisis yang diacu pada Tabel 5, 6, dan 7, maka konsep ruang dibagi menjadi tiga yaitu zona inti, zona penyangga, dan zona pengembangan (Gambar 3a). Zona inti merupakan area pasir putih yang menjadi daya tarik utama pantai dan juga sungai yang berada di sisi selatan pantai. Zona penyangga berada di selatan pantai yang dibelah oleh sungai. Area ini perlu diproteksi karena pertama, didominansi oleh vegetasi pohon yang memiliki nilai penting (Nurisyah, 2015). Kedua, untuk menjaga area estuari, ruang hijau di sempadan sungai perlu dipertahankan (Maryono, 2016). Area penyangga juga ditempatkan di sepanjang jalan dengan alasan diproyeksikan suatu saat kawasan ini akan ramai dan menimbulkan bising kendaraan sehingga perlu adanya vegetasi penyangga untuk mereduksi bising. Selain itu, vegetasi juga dapat menjadi filter pandangan untuk menjaga privasi pengguna tapak. Pada perencanaan ini direncanakan adanya pembagian enam ruang mikro yang dibagi berdasarkan aktivitas yaitu resort, gazebo 
yang dapat digunakan untuk piknik dan camping, kuliner, cendera mata, parkir, dan welcome area (Gambar 3b). Hal ini guna mendukung hasil analisis kualitas potensi objek dan atraksi yang pada variabel fasilitas yang menunjukkan skor yang rendah dari seluruh variabel yang dinilai (Tabel 7).

Tabel 6. Hasil penilaian kualitas aspek ekologi dan wisata

\begin{tabular}{lcccc}
\hline \multicolumn{1}{c}{ Variabel } & Bobot & Kriteria & Skor & Nilai \\
\hline A. Aspek Ekologi & \multicolumn{5}{c}{ Semi alami } & 4 & 100 \\
\hline Penutupan lahan & 25 & Tidak bahaya & 4 & 40 \\
Bahaya & 10 & Mendukung & 4 & 100 \\
Tata guna lahan & 25 & & & \\
\hline B. Aspek Wisata & \multicolumn{5}{c}{ Pasir putih kecoklatan } & 4 & 60 \\
\hline Tipe pantai & 15 & Lahan terbuka & 4 & 60 \\
Penutup lahan & 15 & Ada 5-6 kegiatan & 3 & 30 \\
Variasi jumlah kegiatan & 10 & & & 390 (tinggi) \\
\hline Total & &
\end{tabular}

Tabel 7. Hasil penilaian kualitas potensi objek dan atraksi

\begin{tabular}{llc}
\hline Variabel & Kriteria & Skor \\
\hline Letak dari jalan utama & $<4 \mathrm{~km}$ & 4 \\
Estetika dan keaslian & Asimilasi dominan bentuk asli & 3 \\
Atraksi & Terdapat <3 di tempat lain & 3 \\
Fasilitas pendukung & Sarana dan prasarana tidak tersedia & 1 \\
Ketersediaan air & $<0,5 \mathrm{~m}$ & 4 \\
Transportasi dan aksesibilitas & Jalan aspal berbatu, tanpa kendaraan umum & 2 \\
Dukungan dan partisipasi masyarakat & Mendukung & 3 \\
\hline Total & & 20 (tinggi) \\
\hline
\end{tabular}

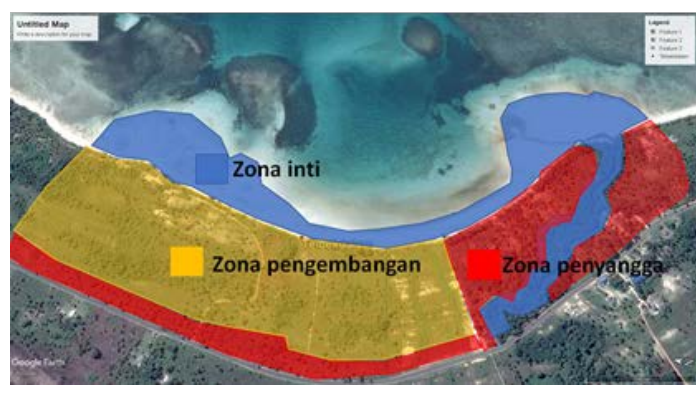

a. Konsep Ruang

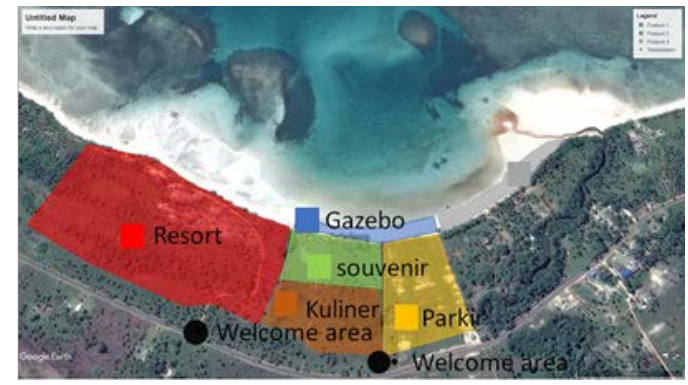

b. Ruang Area Pengembangan

Gambar 3. Konsep Ruang dan Pengambangan Area di Teloek Dalam

Berdasarkan hasil perhitungan luasan area pasir putih sebagai daya tarik utama pantai yaitu sebesar $65.469 \mathrm{~m}^{2}$. Area di luar pasir putih tidak dihitung dalam perhitungan daya dukung karena berdasarkan hasil wawancara masyarakat mengunjungi Pantai Teloek Dalam hanya untuk menikmati pasir putih. Dikhawatirkan, kualitas lingkungan pasir putih akan menurun karena tidak mampu menampung ledakan pengunjung jika area di luar pasir putih juga ikut dihitung. Meskipun kedepannya akan dapat dikembangkan atraksi lainnya, tetapi acuan daya dukung pasir putih tetap menjadi faktor pembatas karena memiliki daya tarik yang lebih besar. Hal yang mendasari pemikiran ini yaitu Hukum Minimum Liebig dan Hukum Toleransi Shelford yang bila 
digabungkan menjadi sebuah konsep faktor pembatas bagi lingkungan. Secara umum Hukum Minimum Liebig menyatakan bahwa faktor penting yang tersedia dalam jumlah mendekati minimum merupakan faktor yang menjadi faktor pembatas. Sedangkan Hukum Toleransi Shelford menyatakan kelebihan maupun kekurangan sutu faktor apabila masih dalam garis toleransi maksimum pada suatu organisme, dianggap tidak memiliki berpengaruh yang signifikan pada kelangsungan hidup organisme tersebut. Dalam kasus di tapak, tingkat toleransi area pasir putih mungkin baik tetapi tidak pada flora dan fauna yang ada. Untuk itu area pasir putih dijadikan sebagai area pembatasan penentuan daya dukung,

Seorang manusia membutuhkan luasan untuk merasa nyaman sebesar $5 \mathrm{~m}^{2}$ (Harris dan Dines, 1988). Sehingga kapasitas jumlah pengunjung yang mendukung kenyamanan yaitu sebesar 12.493 orang. Hasil survei dan observasi di Pantai Teloek Dalam, diperoleh hasil sosial masyarakat sekitar mendukung dan menyambut positif apabila Pantai Teloek Dalam dikembangkan. Rata-rata pengunjung menghabiskan waktu sekitar 4 jam pada sekali kunjungan di pantai. Aktivitas yang dilakukan di pantai antara lain berenang, piknik, memancing, mencari kerang, dan bermain bola di pantai. Asumsi yang digunakan berdasarkan hasil analisis daya dukung dan sosial, pengunjung yang mendukung kenyamanan yaitu sebesar 12.493 orang dengan ratarata kunjungan selama 4 jam. Sehingga diasumsikan setiap penambahan 4 jam akan ada pengunjung yang dapat masuk-keluar kawasan sebanyak 3123 orang. Hasil survei kepada pengunjung didapatkan bahwa pengunjung area pantai memiliki kemampuan bayar sebesar Rp25.000. Sehingga untuk menjaga jumlah pengunjung agar tidak melebihi daya dukung, tarif masuk kawasan yang disarankan adalah sebesar Rp25.000. Pada akhir pekan umumnya meningkat sehingga dapat diberlakukan tarif di atas itu.

Area resort di zona pemanfaatan diasumsikan jika pada satu periode 4 jam ada 3123 orang keluar, maka lokasi masih dapat menampung sekitar 9370 orang yang dapat menginap. Asumsi selanjutnya jumlah kebutuhan kamar yang dapat dilakukan dibagi menjadi tiga kelas yaitu 50\% cottage, 40\% resort, dan 10\% gazebo yang dapat digunakan untuk camping seperti kebiasaan masyarakat setempat. Artinya sebaran pengguna yang dapat menginap di resort sebanyak 4685 orang, cottage 3758 orang, dan di gazebo 937 orang.

Untuk perhitungan jumlah kebutuhan kamar diasumsikan dalam satu kamar resort dan satu kamar cottage dapat menampung masing-masing 2 orang, serta satu gazebo dapat menampung 4 orang, maka kebutahan kamar cottage maksimal sebanyak 2342 kamar, resort maksimal 1874 kamar, dan gazebo 234 buah. Selain itu kebutuhan fasilitas parkir diberikan asumsi 40\% pengunjung menggunakan mobil, $50 \%$ motor, dan 10\% bus. Berdasarkan standar Direktorat Bina Sistem Lalu Lintas Angkutan Kota Dirjen Perhubungan Darat, luas kebutuhan lahan mobil parkir sebesar $5 \times 3,5 \mathrm{~m}^{2}$, motor $2 \times 0,75 \mathrm{~m}^{2}$, dan bus sebesar $12,5 \times 3,4 \mathrm{~m}^{2}$ (Abubakar et al., 1998). Artinya diperlukan lahan parkir mobil sebesar $17.490 \mathrm{~m}^{2}$, motor $4685 \mathrm{~m}^{2}$, dan bus $53.095 \mathrm{~m}^{2}$. Dengan demikian, dibutuhkan area parkir sebesar $72.270 \mathrm{~m}^{2}$.

Kawasan wisata di Pantai Teloek Dalam masih dibutuhkan banyak atraksi wisata untuk meningkatkan daya tarik wisatawan. Berdasarkan hasil wawancara, pilihan wisata di sekitar masih sedikit dan atraksi yang ditawarkan cenderung monoton. Pada konsep perencanaan kawasan wisata ini terdapat 13 aktivitas yang dapat dilakukan oleh wisatawan antara lain memancing, berperahu, mencari kerang, berenang, berfoto, piknik, dan bola pantai. Selanjutnya pengunjung juga dapat melakukan aktivitas voli pantai, bermain layangan, menginap, memandangi sunrise, membeli cendera mata, dan kuliner (Gambar 4). Aktivitas tersebut dapat dilakukan di dua dari tiga ekosistem yang ada pada tapak, yaitu ekosistem pantai dan padang lamun. Sensitivitas estuari sangat rentan sehingga area ekosistem sekitar sungai tidak dibuka untuk menjaga keberlanjutannya. Area terestrial di ekosistem pantai memiliki luas daratan yang cukup dan memungkinkan untuk dikembangkan. Selanjutnya, area akuatik menyimpan manfaat lebih dari sekedar kegiatan rekreasi. Alasannya adalah karena ekosistem lamun memiliki nilai penting yang menjadikan kawasan ini kaya akan keanekaragaman fauna air seperti gonggong yang merupakan satwa khas pantai ini. Terlebih pengembangan wisata berbasis ekosistem lamun masih jarang dilakukan dikembangkan di Indonesia (Kordi, 2011).

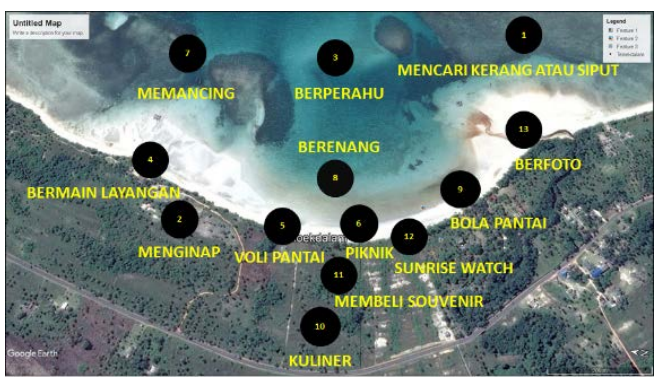

Gambar 4. Konsep Aktivitas Wisata 


\section{Simpulan}

Perencanaan lanskap berkelanjutan memiliki tantangan yang besar menyeimbangkan ekologi, ekonomi, dan sosial-budaya. Penggunaan analisis yang menyeluruh beserta konsep yang tepat, bukanlah hal yang tidak mungkin dalam mencapai keberlanjutan tersebut. Konsep perencanaan yang digunakan dalam kajian ini yaitu ecomparism. Konsep ini merupakan konsep baru yang secara hierarki berada di antara konsep ekowisata dengan konsep wisata konvensional. Konsep ini dipilih dengan pertimbangan bahwa kawasan Pantai Teloek Dalam berdasarkan hasil analisis tautan lingkungan, visual, sosial, ekositem, vegetasi, dan satwa merupakan kawasan yang berpotensi untuk wisata namun sensitif terhadap kerusakan. Konsep ecomparism mempertimbangkan semua aspek tersebut dengan melakukan perencanaan yang memperhatikan daya dukung, untuk menyelaraskan aktivitas wisata untuk mencapai keberlanjutan kawasan.

\section{Ucapan Terima Kasih}

Sebagian dari hasil kajian ini pernah mendapatkan peringkat lima dalam lomba poster perencanaan lanskap pesisir berkelanjutan pada Seminar Nasional Himaskap yang diadakan di Universitas Tribhuwana Tunggadewi - Malang, Maret 2018. Untuk itu penulis berterima kasih kepada seluruh pihak yang membantu selama pelaksanaan studi terkhusus Program Studi Arsitektur Lanskap ISTN yang memberikan bantuan moral dan materil.

\section{Daftar Pustaka}

Abubakar, I., E.A. Sinaga, Budiarso, T. Sinulingga, T.G. Agung, N. Sembiring, N. Djajasinga, B.H. Surti, R. Genting, A. Yani, C. Nurida, E. Sutiono, dan T. Supono. 1998. Pedoman perencanaan dan pengoperasian fasilitas parkir. Direktorat Bina Sistem Lalu Lintas dan Angkutan Kota, Jakarta.

BPS Kepulauan Riau. 2017. Kepulauan Riau dalam angka. BPS, Tanjung Pinang.

Ceballos-Lascurain, H. 1987. The future of ecotourism. Mexico Journal, 1(1987): 13-14.

Fitriana, D.A., L.S. Yusiana, dan I.G.A. Gunadi. 2018. Perencanaan lansekap ekowisata pesisir di Desa Beraban, Kecamatan Kediri, Kabupaten Tabanan. Jurnal Arsitektur Lanskap, 4 (1):1-9.

Gunn C.A. 1994. Tourism planning: basic, concept, case. Taylor \& Francis, Washington DC.

Harris, C.W. dan N.T. Dines. 1988. Time-saver standard for landscape architecture. McGraw-Hill, Singapore. Holden A. 2000. Environment and tourism. Routledge, London.

Ilahi, I., A. Mulyadi, dan D. Yoswaty. 2016. Potensi pengembangan ekowisata di Kawasan Konservasi Lamun Trikora, Bintan, Kepulauan Riau. Berkala Perikanan Terubuk, 44 (3):100-114.

Inskeep E. 1991. Tourism planning: an integrated and sustainable tourism development approach. Van Nostrand Reinhold, New York.

Kordi, M.G.H. 2011. Ekosistem lamun (seagrass): fungsi, potensi, dan pengelolaan. Rineka Cipta, Jakarta.

Makalew, A.D., V.D. Damayanti, dan J.A. Nugraha. 2013. Perencanaan lanskap wisata Pantai Tanjung Baru berbasis eco-landform. Jurnal Lanskap Indonesia, 5 (1): 27-40.

Maryono, A. 2016. Reformasi pengelolaan sumber daya air. Gadjah Mada University Press, Yogyakarta.

Muflih, A, A. Fahrudin, dan Y. Wardiatno. 2015. Kesesuaian dan daya dukung wisata pesisir Tanjung Pasar dan Pulau Untung Jawa. Jurnal IImu Pertanian Indonesia, 20 (2): 141-149.

Nasrullah, N., B. Sulistyantara, D. Sukma, D. Hutapea, H. Zakia, A. Susanto, N. Basuki, A. Hendra, D. Exva, S. Noor, F. Nuraini, M. Harnaz, O.R. Yeni, R. Simbolon, Suharto, dan D. Prihartono. 2016. Informasi teknis tanaman pot dan lanskap. Direktorat Buah dan Florikultura Kementerian Pertanian, Jakarta.

Nurisyah, S. 2015. Pendugaan nilai pohon di kota. IALI, Jakarta.

Syahadat, R.M., P.T. Putra, P. Ramadanti, D. Radnawati, dan S. Nurisjah. 2018. Identifikasi Keanakaragaman Hayati RTH Kota Depok. NALARs Jurnal Arsitektur, 17 (1): 29-38.

Yong, J.W.H., T.P. Yok, N.H. Hassan, dan T.S. Ngin. 2010. A selection of plants for greening of waterways and waterbodies in the tropics. Centre for Greenery and Ecology, Singapore.

Yusiana, L.S., S. Nurisjah, dan D. Soedharma. 2011. Perencanaan lanskap wisata pesisir berkelanjutan di Teluk Konga, Flores Timur, Nusa Tenggara Timur. Jurnal Lanskap Indonesia, 3 (2): 66-72. 